\title{
Optimalisasi Potensi Wisata Religi Di Desa Landangan, Kec. Kapongan, Kab. Situbondo Melalui Company Profile
}

\author{
Mei Artanto, Panakajaya Hidayatullah, Sigit Setiawan \\ Fakultas Ilmu Budaya, Universitas Jember \\ flautacloth@gmail.com
}

\begin{abstract}
Abstrak
Pada tahun 2019 pemerintah Kabupaten Situbondo telah mencanangkan program Situbondo Tahun Kunjungan Wisata 2019 sebagai salah satu upaya meningkatkan potensi daerah yang dapat meningkatkan regulasi ekonomi daerah. Merespon program tersebut lantas membuat tim pengabdian Universitas Jember ini berupaya dalam melakukan pengembangan dari segi pengetahuan, keterampilan dan keahlian dalam pengelolaan potensi wisata religi, yang dalam hal ini masih pada tahap program strategis dalam pemasaran melalui pembuatan company profile Desa Landangan, Kec. Kapongan, Kab. Situbondo. Terlebih Desa Landangan saat ini masih belum memiliki media audio visual yang berisi konten potensi desa, sehingga upaya pembuatan company profile merupakan salah satu solusi dalam menjawab program yang dicanangkan oleh Kab. Situbondo. Metode pelaksanaan dalam program pengabdian ini dibagi menjadi tiga tahapan, yakni 1) tahap persiapan yang terdiri atas observasi, dan penyusunan program produksi company profile; 2) tahap pelaksanaan yang terdiri atas pembuatan company profile dengan konten potensi wisata religi sebagai strategi pengenalan tempat destinasi wisata kepada khalayak umum; 3) tahap evaluasi. Diharapkan dengan adanya company profile wisata religi, Desa Landangan memiliki media untuk mempromosikan potensi wisata religi, seperti proses upacara petik laut, Asta Buju' Kaji dan Al-Quran Sejimat sehingga ditahun 2019 telah siap menyambut Situbondo Tahun Kunjungan Wisata 2019.
\end{abstract}

Kata Kunci: Company profile, Wisata religi, Desa Landangan, Sosial media

\section{PENDAHULUAN}

Pemerintah Kabupaten Situbondo telah mencanangkan program 'Situbondo Tahun Kunjungan Wisata 2019'. Menurut Bupati dan Wakil Bupati Situbondo, yaitu Dadang Wigiarto dan Yoyok Mulyadi, program 'Situbondo Tahun Kunjungan Wisata 2019' akan menjadi program prioritas di mana seluruh elemen perangkat daerah agar bersinergi dalam menyongsong terlaksananya program tersebut ${ }^{1}$. Guna menuju kabupaten tujuan wisata tidak serta merta hanya bisa dilakukan oleh Dinas Pariwisata, melainkan juga didukung oleh divisi-divisi dimasing-masing dinas yang terkait dalam program tersebut ${ }^{2}$. Tidak hanya itu, bagi tim pengabdian Universitas Jember keaktifan dan peran dari masyarakat Situbondo juga menjadi aspek penting dalam menyukseskan program tersebut. Lantas untuk potensi wisata sendiri, Situbondo tidak hanya menyuguhkan pesona alam sebagai destinasi wisata, melainkan memiliki potensi untuk wisata religi. Terlebih bagi kota yang menyandang nama sebagai Kota Santri dan Bumi Sholawat potensi akan tempat-tempat destinasi spiritual perlu untuk segera dimunculkan dan diinformasikan kepada khalayak umum. Karena bukan tidak mungkin Situbondo kelak menjadi seperti dan bahkan dapat melebihi destinasi wisata religi yang sudah ada sebelumnya, seperti di

\footnotetext{
${ }^{1}$ https://jatim.antaranews.com/berita/246056/situbondo-canangkan-tahun-kunjungan-wisata-2019

${ }^{2}$ https://jatim.antaranews.com/berita/246056/situbondo-canangkan-tahun-kunjungan-wisata-2019
} 
daerah Demak, Kudus, dan tempat-tempat Ziarah Wali Songo dan wali yang lain. Bahkan saat ini tempat-tempat spiritual seperti di Demak, Kudus, dan Madura sudah menjadi wilayah destinasi favorit untuk wisata religi dan kini sudah banyak bermunculan biro perjalanan yang menawarkan paketan wisata tersebut ${ }^{3}$. Hal ini yang kemudian memicu betapa pentingnya dan segeranya dilakukan upaya-upaya strategis untuk mengangkat potensi wisata religi yang ada di Situbondo, yang salah satu potensi wisata religi ini ada di sisi timur pusat kota Situbondo, yaitu Desa Landangan, Kecamatan Kapongan.

Berdasarkan sumber dari mahasiswa/wi Kuliah Kerja Nyata 235 (KKN) Universitas Jember Periode II Tahun 2017/2018 yang tertuang dalam buku Di Balik Desa Landangan, Desa Landangan memiliki potensi wisata religi seperti adanya beberapa bentuk-bentuk ritual, cerita, dan mitos yang erat kaitannya dengan hal-hal yang bersifat mistis serta telah menjadi kepercayaan di masyarakat. Menariknya, proses ritual, adanya cerita, dan mitos-mistos ini saling terkait satu sama lain dalam proses pelaksanaannya di mana masing-masing potensi tersebut berkontribusi. Keterhubungan dari masing-masing potensi, seperti ritual Petik Laut, Asta Juko (Kuburan Ikan), Ju' Kaji (dipercaya sebagai leluhur desa Landangan), Al-Qur'an Sejimat, dan mitos Sekorseh (Mahasiswa/wi KKN 235 Universitas Jember Periode II Tahun 2017/2018, 2018: 18-24). Melihat potensi ini kiranya dapat menjadi modal kuat untuk pemerintah beserta jajarannya segera menyusun dan mengemas potensi ini sebagai salah satu aset penting dalam salah satu wilayah yang harus dikunjungi sebagai obyek wisata religi. Dan produk dari mahasiswa/wi Kuliah Kerja Nyata 235 (KKN) Universitas Jember Periode II Tahun 2017/2018 seperti buku sebagai pusat data dan pencatatan mengenai potensi wisata religi yang ada di Desa Landangan menjadi modal penting untuk melanjutkannya dengan program lainnya.

Akan tetapi upaya merespon potensi wisata tersebut belum diperlihatkan oleh pemerintah desa. Sejauh ini upaya yang dilakukan masih pada upaya pencatatan data dan deskripsi mengenai tempat-tempat wisata religi, itupun dilakukan oleh mahasiswa/wi Kuliah Kerja Nyata 235 (KKN) Universitas Jember Periode II Tahun 2017/2018 melalui buku 'Di Balik Desa Landangan'. Upaya ini dirasa kurang strategis sebagai langkah untuk merespon tahun 2019 Situbondo sebagai tahun kunjungan wisata. Hal yang bisa dilakukan yaitu membuat program wisata dengan melibatkan pemerintah desa serta masyarakat. Program wisata ini tentu akan menyajikan potensi-potensi wisata dengan melibatkan peran teknologi, seperti sosial media dan audio visual. Dan itu nampaknya belum diperhatikan oleh pemerintah Desa Landangan sebagai upaya merespon program dari Bupati dan Wakil Bupati Situbondo. Terlebih di bulan November 2018 ini akan diadakan upacara Petik Laut. Ini menjadi momen yang tepat untuk mengembangkan potensi wisata ini, di mana segala rangkaian upacara tersebut dapat dijadikan obyek penting untuk membuatkan program sebagai upaya strategis mempromosikan obyek wisata religi.

Lantas berdasarkan hal tersebut, serta merespon program prioritas dari pemerintah Kabupaten Situbondo dalam program 'Situbondo Tahun Kunjungan Wisata 2019' dan mengembangkan capaian dari mahasiswa/wi Kuliah Kerja Nyata 235 (KKN) Universitas Jember Periode II Tahun 2017/2018, kami melihat bahwa kedua program ini dapat bersinergi untuk menuju pada tercapainya program dari pemerintah |Kab. Situbondo sebagai Kota Wisata. Maka untuk mempertemukan program ini agar bersinergi kami menawarkan program optimalisasi peran video profil dan sosial media sebagai strategi promosi pariwisata. Mengapa media sosial media? Bagi kami dalam era yang serba cepat dan berbasis pada penguasaan perangkat teknologi, dalam upaya mesukseskan program Situbondo Tahun Kunjungan Wisata 2019 ini

\footnotetext{
${ }^{3}$ https://www.bromotourpaket.com/2015/01/paket-wisata-religi-wali-songo-murah-2015.html
} 
perlu adanya upaya peningkatan peran company profile sebagai strategi pemasaran pariwisata. Artinya video profil dengan konten-konten lokasi wisata religi nantinya para petualang wisata religi akan mendapatkan informasi secara jelas terkait destinasi menarik yang ada di Desa Landangan. Selain itu melalui company profile ini, hasil pencatatan mahasiswa/wi Kuliah Kerja Nyata 235 (KKN) Universitas Jember Periode II Tahun 2017/2018 dapat diterjemahkan kembali sebagai konten informasi perihal sejarah dan nilai-nilai yang terkadung dari masing-masing tempat dengan kecenderungan kondisi distribusi informasi wisata melalui sosial media hari ini namun tetap tanpa menghilangkan esensi informasi dan nilai-nilai yang terkandung di dalamnya.

Program optimalisasi peran video profil sebagai strategi pengenalan destinasi wisata bukan sesuatu yang baru dalam upaya promosi lokasi wilayah wisata saat ini. Artinya melalui kehadiran video dalam upaya mempromosikan tempat-tempat destinasi wisata menjadi hal penting dalam menentukan animo kunjungan para wisatawan, yang nantinya akan beriringan dengan upaya peningkatan infrastruktur sebagai upaya memberi kenyamanan kepada para wisatawan. Dan untuk program ini, kami akan fokus pada penerjemahan data-data yang ada pada buku 'Di Balik Desa Landangan' sebagai konten informasi dalam upaya merancang program wisata religi Desa Landangan, serta melengkapinya dengan data-data sejarah dari para narasumber yang kirannya penting sebagai penguat nilai dalam konten video profil.

Selain itu hal yang juga perlu dilakukan yaitu memberikan pengetahuan dan ketrampilan pengoperasian sistem teknologi berbasis sosial media sebagai upaya mempromosikan tempattempat yang berpotensi sebagai lokasi wisata. Melalui program ini, yaitu mengoptimalisasikan konten informasi potensi wisata dalam upaya strategi pengenalan destinasi wisata berbasis sosial media serta peningkatan pengetahuan dan ketrampilan pengoperasian system yang berbasis sosial media sebagai strategi pengenalan lokasi destinasi wisata diharapkan dapat menjadi langkah awal bagi Desa Landangan untuk mensukseskan program pemerintah Kabupaten Situbondo yang akan menjadikan Situbondo sebagai kota wisata dan mengembangkan capaian dari mahasiswa/wi Kuliah Kerja Nyata 235 (KKN) Universitas Jember Periode II Tahun 2017/2018.

\section{METODE PELAKSANAAN}

Rangkaian kegiatan pengabdian yang akan dilakukan dengan mitra pengabdian secara umum mempunyai persoalan yang kompleks dan beragam. Hal ini disebabkan karena adanya potensi wisata religi yang masing-masing potensi saling berkaitan satu sama lain. Namun itu menjadi keuntungan dalam proses pembuatan company profile, di mana nantinya profil ini akan menyajikan konten potensi wisata religi secara menyeluruh serta tetap menghadirkan kontenkonten spesifik dari potensi itu. Selain itu, company profil ini juga dapat digunakan sebagai upaya mengedukasi kepada masyarakat sekitar mengenai khasanah kekayaan kearifan lokal yang ada diwilayah tersebut. Lantas Berdasarkan permasalahan yang ditemukan serta pentingnya posisi kegiatan ini sebagai upaya merespon program dari Kabupaten Situbondo serta mengangkat potensi wisata, maka proses pelaksanaan kegiatan pengabdian ini memiliki tiga tahapan utama, yaitu persiapan, pelaksanaan, dan evaluasi.

\section{A. Tahap Persiapan}

Persiapan, atau yang dalam bahasa pengelolaan kegiatan dapat disebut dengan sebutan praproduksi yang menjadikan tahap awal yang harus ditempuh. Tahap ini dilakukan untuk mengetahui potensi apa saja yang akan dibutuhkan sebagai bekal untuk melanjutkan ke tahap pelaksanaan. Dan untuk tahap ini akan dibagi menjadi dua kegiatan, yaitu observasi dan penyusunan program kegiatan. 


\section{Observasi}

Pada tahap observasi ini meliputi upaya menggali potensi-potensi wisata religi yang ada dilapangan guna pengkayaan data-data yang sudah ada. Data-data tersebut penting bagi pelaksanaan program ini, karena melalui data tersebut pelaksana dapat melakukan pemetaan dan klasifikasi permasalahan untuk kemudian dianalisis guna memperoleh rumusan penyusunan program yang solutif bagi permasalahan yang ada. Berdasarkan observasi ini, terdapat beberapa potensi wisata religi yang menarik untuk menjadi objek dalam company profile, yaitu ritual Petik Laut, Asta Juko (Kuburan Ikan), Ju' Kaji (dipercaya sebagai leluhur desa Landangan), Al-Qur'an Sejimat, dan mitos Sekorseh. Setelah melakukan observasi dan data yang dibutuhkan diperoleh, maka beranjak pada penyusunan program.

\section{Penyusunan Program}

Penyusunan program menjadi tahap selanjutnya setelah tahap observasi dilakukan, di mana data-data yang diperoleh kemudian akan dianalisis guna mencari potensi yang optimal dari objek wisata religi sehingga mendapatkan stock shoot yang bagus untuk pemasaran wisata religi. Penyusunan rancangan keseluruhan program ini menititk beratkan pada hal-hal teknis dilapangan serta pembagian tugas untuk mengambil shoot dari masing-masing objek wisata religi. Hal itu diperlukan agar mendapatkan momentum yang bagus, terlebih dalam upacara petik laut.

\section{B. Tahap Pelaksanaan}

Setelah observasi dan penyusunan program, selanjutnya menuju pada tahap pelaksanaan. Segala kegiatan dalam tahap pelaksanaan ini didalam pelaksanaanya mengikuti skema rancangan kegiatan, di mana waktu pelaksanaan dilakukan mengikuti kondisi lapangan. Artinya pelaksanaan program ini seperti pembuatan website tentu mengikuti situasi dan kondisi lapangan, karena hal itu berhubungan dengan proses pengambilan data-data seperti shoot sebagai konten dalam pembuatan video profil.

1. Pembuatan Video Profil Wisata Religi Desa Landangan

Keterlibatan jajaran pemerintah desa beserta tokoh-tokoh masyarakat yang memiliki informasi penting terkait potensi wisata religi seperti ritual Petik Laut, Asta Juko (Kuburan Ikan), Ju' Kaji (dipercaya sebagai leluhur desa Landangan), Al-Qur'an Sejimat, dan mitos Sekorseh menjadi hal yang penting. Hal itu dikarenakan sebagai konten yang akan disuguhkan dalam vidoe profil dan website, terlebih persoalan waktu pelaksanaan seperti upacara Petik Laut. Selain menyajikan informasi tempat wisata religi, di dalamnya akan teruat mengenai sejarah, mitos, serta kondisi terbaru dari lokasi-lokasi tersebut, sehingga para wisatawan yang akan berkunjung mendapatkan informasi yang jelas mengenai situasi terkini lokasi wisata religi. Data-data yang sudah terdokumentasi ini kemudian disatukan menjadi kesatuan agar hasilnya akan menyeluruh dengan konten potensi wisata religi.

\section{Evaluasi}

Tahap evaluasi ini dilaksanakan pada proses pembuatan vidoe profil, karena hal itu berhubungan dengan kebutuhan shoot dalam video profil. Evaluasi ini dalam bahasa seni pertunjukan dapat disebut sebagai aftermath. Aftermath sebagai ruang evaluasi, merujuk dari tulisan Dede Pramayoza, dilakukan pada tiga wilayah penting dalam rangkaian kegiatan, yaitu (1) evaluasi atas intepretasi, (2) evaluasi atas efektivitas, dan (3) evaluasi atas relevansi 
(Murgiyanto, 2016: 287). Ketiga wilayah evaluasi ini dilakukan guna secara cepat dapat memberi solusi dan penyelesaian di setiap permasalahan yang terjadi dilapangan dalam proses produksi video profil, yang dilakukan untuk kedua belah pihak, artinya masing-masing pihak dapat memberi evaluasi yang saling mengisi, sehingga dapat berdampak pada terjalinnya dialektika positif bagi kerjasama di waktu sekarang dan di waktu yang akan datang.

\section{III.HASIL DAN PEMBAHASAN}

\section{A. Video Profil Sebagai Srategi Promosi Potensi Wisata}

Jika berbicara pariwisata dan upaya pengenalannya kepada masyarakat luas hari ini, kita tidak dapat melepaskan strategi promosi tanpa menggunakan teknologi, khususnya yang berbasis audio visual. Pada umumnya audio visual ini disebut dengan company profile, yaitu sebuah media yang memiliki konten representasi kondisi dari sebuah perusahaan, organisasi, komunitas, kota, desa, dan tempat-tempat wisata yang bertujuan untuk memperkenalkan produk unggulan mereka kepada khalayak umum, sehingga diharapkan produk tersebut dikenal oleh masyarakat dan bisa menarik perhatian masyarakat untuk dapat mengkonsumsi, membeli, dan menggunjungi konten-konten yang sedang dipromosikan ${ }^{4}$. Maka tidak heran jika saat ini sangat marak penggunaan company profile sebagai strategi untuk mempromosikan produk atau kontenkonten yang sifatnya untuk dapat dikenalkan kepada masyarakat luas. Dan tidak ketinggalan termasuk industri pariwisata juga saat ini menggunakan company profil sebagai strategi efektif dalam mendorong datangnya para wisatawan untuk datang. salah satu contoh, kita membuka laman youtube.com kemudian menuliskan pesona Indonesia atau wonderful Indonesia maka kita akan menemui berbagai company profil dengan konten potensi dan keindahan alam Indonesia yang ingin dikenalkan kepada masyarakat luas, tidak hanya skala nasional melainkan internasional.

Terlebih penggunaan company profile ini disertai dengan dikaitkannya dengan jaringanjaringan sosial media sehingga distribusi dari company profile ini akan semakin tidak terbatas jangkauannya. Hal itu juga ditegaskan oleh Muhammad Faried, bahwa melalui optimalisasi basis online promosi wisata akan semakin dapat dimaksimalkan untuk mendatangkan para wisatawan, terlebih jika di dalam konten tersebut mengarah pada potensi-potensi yang ingin ditawarkan ${ }^{5}$. Berdasarkan hal itu kiranya sangat tepat jika dalam kesempatan pengabdian masyarakat ini kami selaku tim berupaya untuk membuat company profile Desa Landangan, Kec.Kapongan, Kab.Situbondo sebagai langkah menjawab tantangan promosi wisata yang berbasis audio visual serta mendukung program pemerintah Kabupaten Situbondo, yaitu Situbondo Tahun Kunjungan Wisata 2019.

Penggunaan audio visual, seperti video profil sebagai strategi dalam memasarkan potensi wisata menjadi hal yang sangat perlu dilakukan, karena melalui audio visual ini masyarakat yang semula tidak mengetahui mengenai potensi wisata desa menjadi lebih mengenal dan memahami. Upaya semacam ini yang coba dilakukan oleh kami tim pengabdian kepada Desa Landangan, Kec. Kapongan, Kab. Situbondo.

Lantas berbicara konten yang akan dimasukkan dalam video profil wisata Desa Landangan, tentu kita terlebih dahulu akan melihat kondisi geografis serta aktfitas kultural di sana. Sejauh observasi, desa yang berada di pesisir utara Situbondo memiliki keragaman aktifitas kultural yang tidak hanya di dominasi oleh masyarakat yang bekerja sebagai nelayan saja, melainkan ada yang bercocok tanam atau bertani, dan berwirausaha. Selain itu, konten yang perlu dimasukkan dalam video profil adalah kegiatan yang bersifat ceremonial, dan di Desa

\footnotetext{
${ }^{4}$ http://www.lumi-one.com/newsfeed/kelebihan-dan-kegunaan-video-company-profile

5 https://lifestyle.kompas.com/read/2011/12/16/15534448/inilah.tiga.strategi.promosi.wisata.2012
} 
Landangan terdapat upacara Petik Laut yang diselenggarakan oleh desa setiap tahun sekali. Dan menariknya dalam kurun waktu pengabdian ini, tim menemukan momentum yang baik untuk dimasukkan sebagai konten video profil, yaitu upacara Petik Laut. Menariknya dalam proses upacara Petik Laut ini berkaitan dengan beberapa situs religi yang penting bagi masyarakat Desa Landangan, yaitu Ju' Kaji dan AL-2ur'an Sijimat.

Kemudian setelah mendapat konten terkait aktifitas kultural, selanjutnya mengambil keterangan terkait kondisi desa dan aktifitas kultural, seperti upacara Petik Laut kepada pemerintah desa, yang diwakili oleh kepala desa serta salah satu tokoh masyarakat yang mengetahui mengenai sejarah desa, maupun adanya potensi wisata religi. Hal itu penting agar dalam proses pembuatan video profil ini memiliki informasi penting terkait potensi wisata religi seperti upacara Petik Laut, petilasan Ju' Kaji (dipercaya sebagai leluhur desa Landangan), dan Al2ur'an Sejimat.

\section{B. Proses Pembuatan Video Profil}

Proses pembuatan company profile yang berbentuk video/audio visual terdapat tiga tahapan yang harus dilakukan, yaitu pra-produksi, produksi, dan paska produksi. Pra-produksi atau dapat disebut tahap persiapan, di mana segala sesuatu kebutuhan, seperti diskusi penentuan konten, persiapan peralatan, metode pelaksanaan dilapangan, menentukan tempat yang baik untuk mengambil gambar, logistik dilapangan, dan momentum apa saja yang ingin diambil gambar dalam proses produksi harus dipersiapkan sedemikan rupa agar tidak ada kendala dalam proses produksi. Selanjutnya setelah para tahap ini selesai maka dapat beranjak pada tahap kedua, yaitu produksi

Pada tahap produksi ini merupakan realisasi dari tahap pra-produksi di mana metode pelaksaanaan guna mendapatkan semua kebutuhan gambar atau stock shoot untuk video yang sudah dirancang dengan segera untuk dapat diperoleh. Apalagi dalam produksi kali ini berhubungan dengan sebuah momentum yang tidak dapat diulang, seperti proses rangkaian upacara petik laut yang dilakukan oleh masyarakat Desa Landangan satu kali dalam setahun di mana dalam proses ini juga membuka dan membaca Al-Qur'an Sejimat yang menurut juru kunci hanya boleh dibuka dua kali dalam setahun. Bagi tim, momentum ini sangatlah penting untuk dimasukkan ke dalam company profile karena upacara petik laut dapat dikatakan sebagai sebuah pertunjukan budaya. Artinya dalam tradisi tersebut memiliki muatan kultural yang ada pada media yang ditransformasikan oleh manusia yang medukungnya yang diwujudkan dalam bentuk pertunjukan (Murgiyanto, 2015: 28). Pertunjukan di sini merujuk pada definisi yang berati adanya komunikasi dengan maksud menyampaikan pesan kepada penerima atau penonton melalui berbagai media, seperti gerak, visual, maupun audio (2015: 20), dan dalam hal ini upacara petik laut termasuk dalam lingkup definis tersebut. Terlebih upacara semacam ini dapat memiliki fungsi ganda, yaitu pertunjukan yang berfungsi sebagai sarana ritual dan hiburan pribadi maupun kolektif (Soedarsono, 2010: 125 dan 199). Berdasarkan hal itu maka momentum ini sangat penting untuk dimasukkan dalam konten company profile. Berikut dokumentasi dalam proses produksi video profil potensi Desa Landangan, Kec. Kapongan, Kab. Situbondo. 


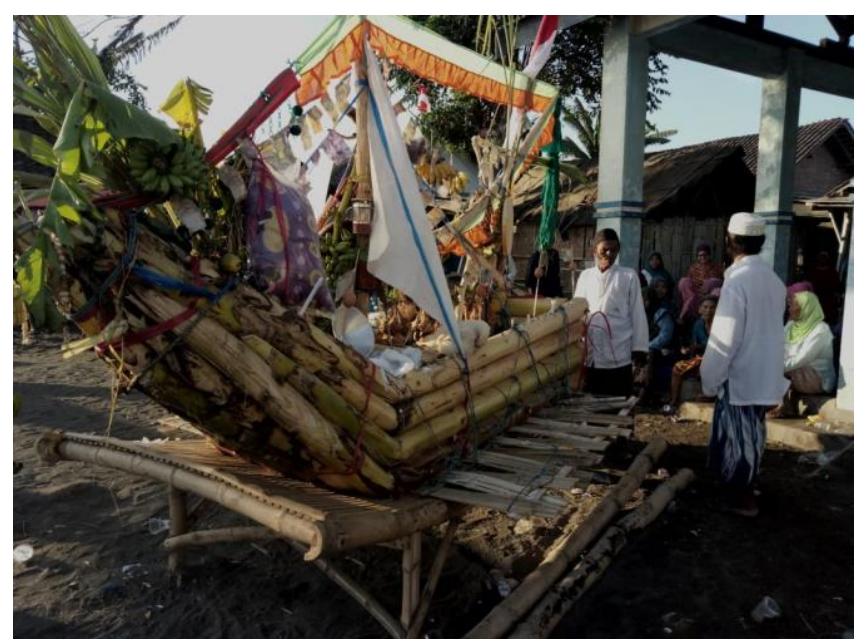

Gambar l. Bhitek yaitu tempat hasil bumi yang akan dilarung ke laut.

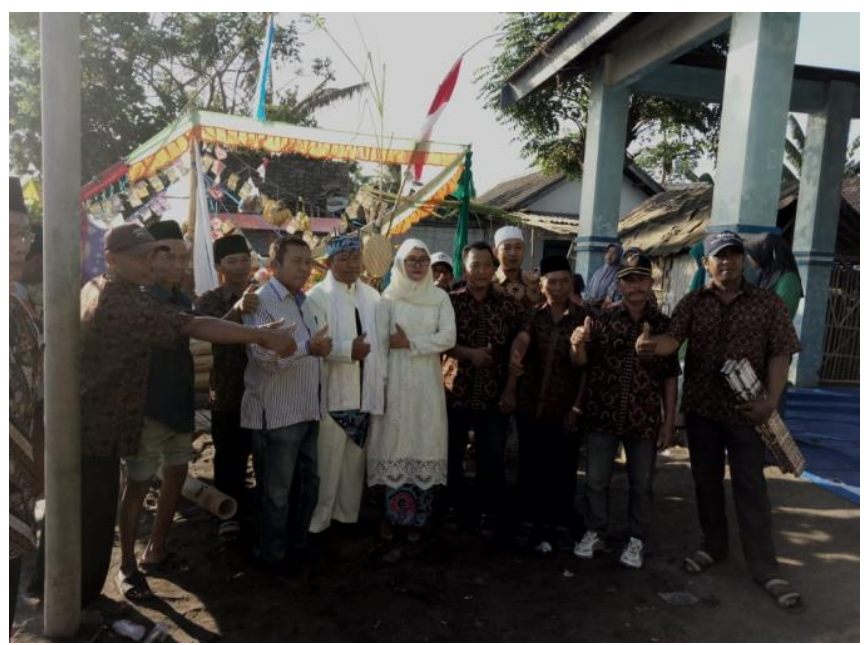

Gambar 2. Pak Tenggi dan tokoh masyarakat sebelum melarung Bhitek

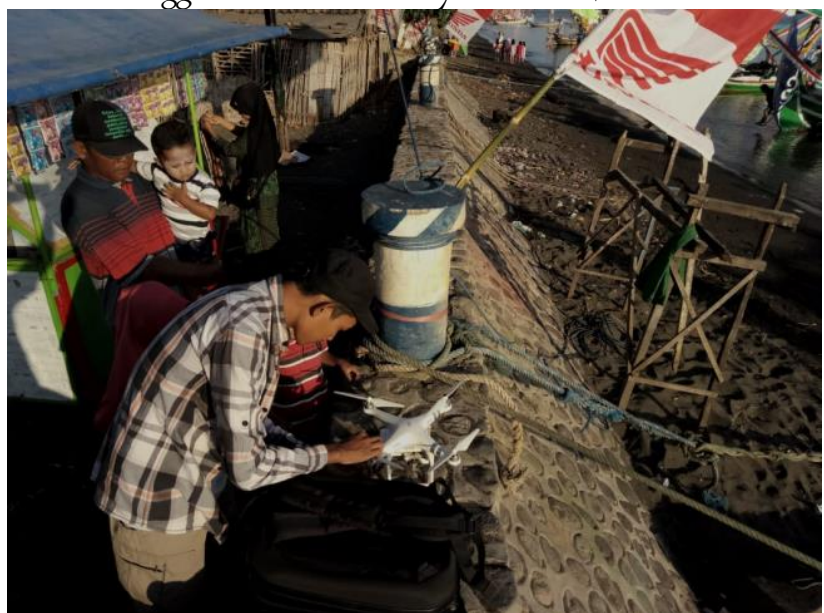

Gambar 3. Proses persiapan penerbangan drone 


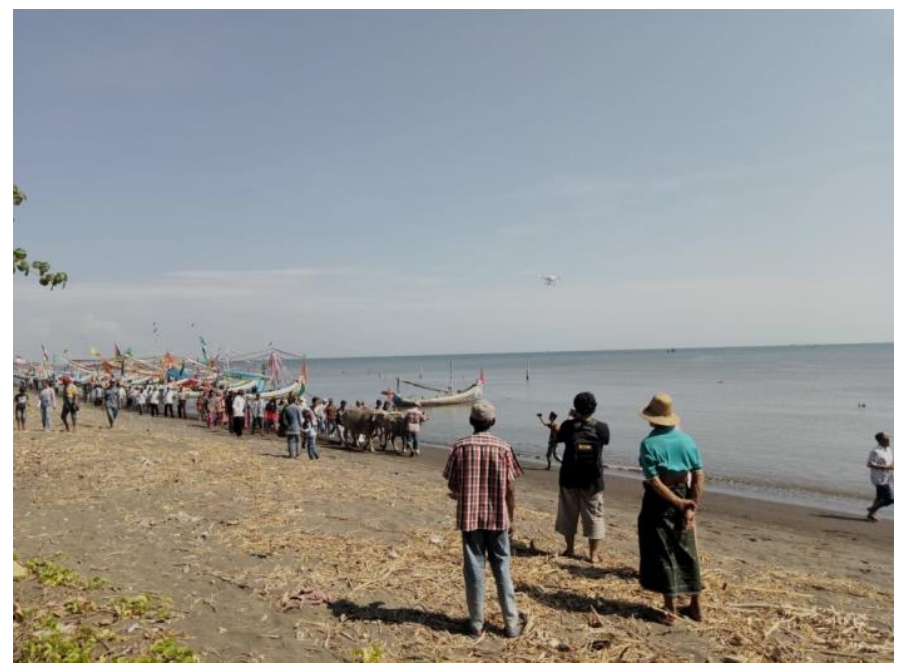

Gambar 4. Proses Asaka' yaitu membajak pantai setelah melarung Bhitek

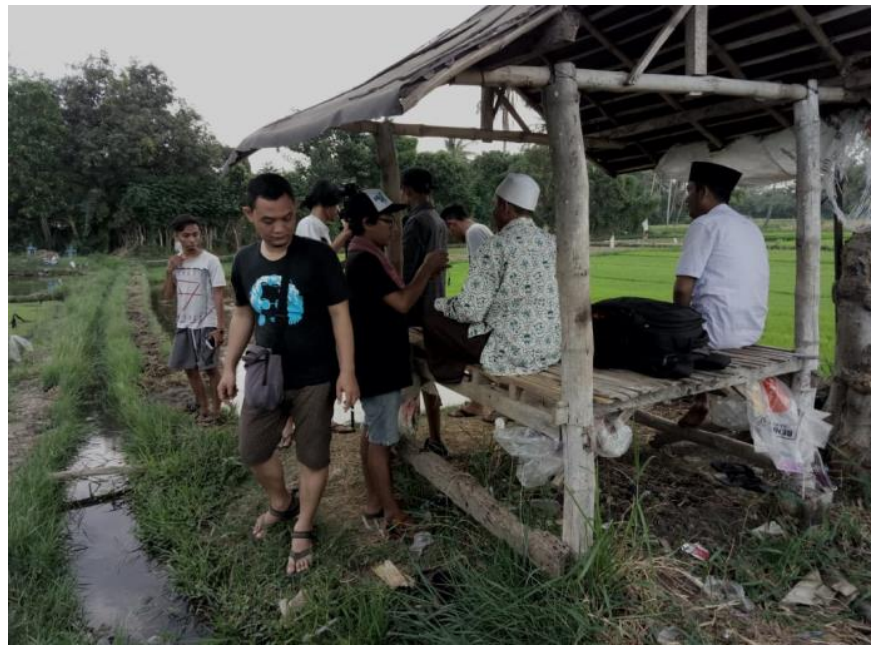

Gambar 5. Proses persiapan pengambilan shoot dengan tokoh masyarakat.

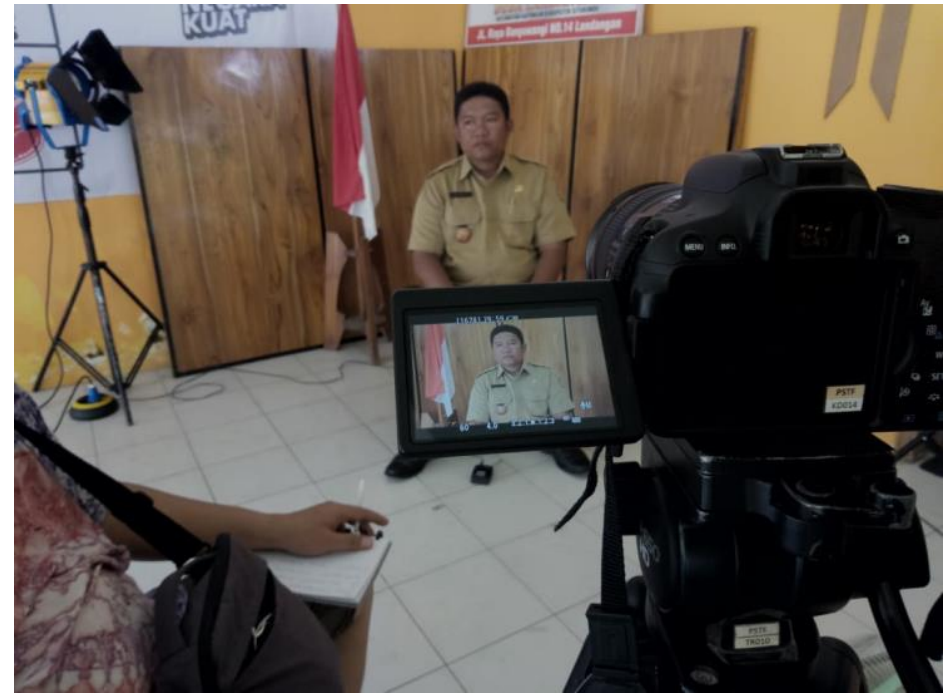

Gambar 6. Proses pengambilan shoot dengan kepala desa atau Pak Tenggi 
Selanjutnya setelah seluruh gambar atau stock shoot yang dibutuhkan telah diperoleh tahap selanjutnya dalam proses pembuatan ini yaitu paska produksi. Paska produksi ini meruapakan proses penting dalam pembuatan company profile dikarenakan dalam proses ini semuan shoot yang sudah ada kemudian masuk dalam tahap editting. Proses editting ini dilakukan dalam dua tahap, yaitu offline (menyeleksi, menyusun gambar, dan memberi suara untuk panduan bagi ilustrator musik) dan online (koreksi warna, efek, pemberian judul, voice over, dan musik ilustrasi). Jika dua proses tersbut sudah dilakukan maka video profil bisa untuk didistribusikan, yang dalam konteks ini diberikan kepada pemerintah desa agar dapat segeran dimanfaatkan sebagai media promosi desa.

\section{IV.KESIMPULAN DAN SARAN}

Penggunaan company profile sebagai upaya mempromosikan sebuah potensi wisata di era saat ini merupakan hal yang sangat diperlukan. Melalui company profile seperti video segala potensi yang ada di desa dapat disajikan secara apik sehingga membuat orang yang melihat merasa tertarik untuk datang. Terlebih jika potensi wisata ini nantinya dapat dijadikan alternatif masyarakat untuk bisa mejalankan roda perekonomian sehingga dapat mensejahterakan masyarakat sekitar. Capaian tersebut yang kiranya ingin dicapai oleh program pengabdian ini, di mana setelah adanya company profile potensi wisata religi yang ada di Desa Landangan ke depan dapat berguna untuk menarik para wisatawan yang memiliki ketertarikan mengunjungi wisata religi. Selain itu juga perlu untuk memikirkan program lanjutan guna mensukseskan program pemerintah kabupaten yaitu Situbondo Tahun Kunjungan Wisata 2019, seperti perbaikan infrastuktur, membentuk organisasi pengelolaan wisata, dan penyelenggaraan acara secara rutin. Hal yang tidak kalah penting yaitu pemahaman kepada masyarakat umum mengenai pengelolaan semacam ini, termasuk keberlanjutan dari keberfungsian company profile sebagai media promosi wisata religi. Keberlanjutan dan konsistensi dalam memanfaatkan social media sebagai media promosi akan menjadi strategi efektif untuk menarik para wisatawan ini agar datang berbondong-bondong mengunjungi wisata religi Desa Landangan dengan segala fasilitas yang telah siap untuk menyambut mereka.

\section{UCAPAN TERIMAKASIH}

Terselenggaranya program pengabdian dengan lancar tentunya didukung oleh berbagai pihak, seperti Lembaga Penelitian dan Pengabdian Masyarakat Universitas Jember yang memberikan kepercayaan dan kesempatan kepada kami untuk dapat merealisasikan program optimalisasi potensi wisata religi Desa Landangan, Kec. Kapongan, Kab. Situbondo melalui pembuatan company profile. Kemudian kepada pemerintah dan masyarakat Desa Landangan yang telah mendukung dan membatu lancarnya proses produksi company profile ini, serta terimakasih kepada Dekan Fakultas Ilmu Budaya Universitas Jember yang telah memberi ijin untuk dapat melaksanakan program pengabdian ini. Dan untuk seluruh pihak yang membantu kelancaran pelaksanaan program pengabdian masyarakat ini.

\section{VI.DAFTAR PUSTAKA}

Mahasiswa Kulah Kerja Nyata 235 (KKN) Universitas Jember Periode II Tahun 2017/2018. 2018. Buku Di Balik Desa Landangan. Situbondo.

Murgianto, Sal. 2015.Pertunjukan Budaya dan Akal Sehat. Jakarta: FSP IKJ dan Komunitas Senripita. 
Murgianto, Sal. 2016. Kritik Pertunjukan dan Pengalaman Keindahan. Jakarta: Pasca IKJ dan Komunitas Senripita

Soedarsono, R.M. 2010. Seni Pertunjukan Indonesia di Era Globalisasi. Yogyakarta: Gadjah Mada University Press.

\section{Sumber elektronik}

http://www.lumi-one.com/newsfeed/kelebihan-dan-kegunaan-video-company-profile, di unduh pada tanggal 19 November 2018.

https://jatim.antaranews.com/berita/246056/situbondo-canangkan-tahun-kunjungan-wisata2019), di unduh pada tanggal 12 September 2018.

https://ifestyle.kompas.com/read/2011/12/16/15534448/inilah.tiga.strategi.promosi.wisata.2012, di unduh pada tanggal 19 November 2018. 